\title{
Pemahaman Ibadah Sejati Berdasarkan Roma 12:1-2 terhadap Pertumbuhan Kerohanian Remaja GPPS Maranata Diski: Studi Eskesegetis
}

\author{
Elfrida Siringo-ringo \\ Pendidikan Agama Kristen, STT Anugerah Sinagoge Medan \\ elfridasiringoringo@yahoo.co.id
}

\begin{abstract}
Abstrak
Pemahaman remaja tentang ibadah sejati masih minim. Penelitian ini bertujuan untuk mengetahui pemahaman ibadah yang sejati berdasarkan Roma 12:1-2 terhadap pertumbuhan kerohanian remaja GPPS Maranatha Diski. Metode penelitian yang digunakan adalah survei kuantitatif. Metode dan alat pengumpulan data adalah dengan angket. Dari hasil penelitian ditemukan: (1) pemahaman remaja tentang Ibadah Yang Sejati Berdasarkan Roma 12:1-2 dalam kategori cukup paham (2) Pertumbuhan Kerohanian Remaja GPPS Maranatha Diski (Y) dalam kategori cukup paham; dan (3) pengaruh pemahaman Ibadah yang sejati berdasarkan Roma 12:1-2 terhadap kategori cukup. Berdasarkan temuan tersebut, perlu dilakukan usaha-usaha memperbaiki pemahaman berkaitan dengan ibadah sejati berdasarkan Roma 112:1-2, yaitu: (a) menyampaikan khotbah yang berkesinambungan tentang pengajaran-pengajaran dasar seperti ibadah yang sejati dan pertumbuhan kerohanian secara berkala; (b) membagikan kepada jemaat bahan pengajaran dasar; (c) menciptakan dan mengadakan materi pelajaran dengan disain/tampilan yang menarik dan gaya pembahasan yang menarik; (d) mendorong departemen Pemuda/Remaja untuk mengevaluasi peranan orang tua, Sekolah Minggu dan pembina rohani yang ada.
\end{abstract}

Kata-kata kunci: Ibadah sejati, remaja, studi eksegetis

\begin{abstract}
Understanding adolescents about true worship is still minimal. This study aimed to determine the true worship understanding based on Romans 12: 1-2 on the growth of teenager spirituality of GPPS Maranatha Diski. The research method used is quantitative survey. Methods and tools of data collection were used by questionnaire. The results of the study were found: (1) adolescent's understanding of True Worship Based on Romans 12: 1-2 in the sufficiently understood category (2) Spiritual Growth Spirituality GPPS Maranatha Diski (Y) in the category understood enough; and (3) the effect of true worship understanding based on Romans 12: 1-2 on the sufficient category. Based on these findings, efforts should be made to improve understanding of true worship based on Romans 112: 1-2, namely: (a) delivering continuous sermons on basic teachings such as true worship and spiritual growth periodically; $(b)$ distributing to the congregation of basic teaching materials; (c) creating and conducting subject matter with an attractive design / appearance and an interesting style of discussion; (d) encourage Youth / Youth departments to evaluate the role of parents, Sunday School and existing spiritual counselors.
\end{abstract}

Keywords: true worship, adolescents, exegetis study 


\section{PENDAHULUAN}

Ibadah adalah kegiatan rohani yang harus dilakukan oleh setiap orang Kristen. Karena melalui ibadah, orang percaya berjumpa dengan Tuhan Yesus Kristus sehingga dapat mengenal Dia secara pribadi. Ibadah juga perbuatan yang menyatakan bakti kepada Allah yang didasari pada ketaatan untuk mengerjakan perintah-Nya dan menjauhi larangan-Nya, dilakukan dengan segenap hati, lahir dan batin, sesuai dengan perintah Tuhan untuk mendapatkan kebahagiaan dan keselarasan hidup, baik terhadap diri sendiri, keluarga, masyarakat, maupun terhadap alam semesta. Jadi sangat jelas bahwa ibadah merupakan keharusan kepada setiap orang Kristen.

Banyak ajaran Firman Tuhan mengenai sikap benar yang perlu dipahami oleh remaja seperti merawat tubuh dengan baik dan mempersembahkannya kepada Tuhan sebagai persembahan yang hidup, kudus dan berkenan (Rm 12:1). Mengapa hal ini menjadi begitu penting? Karena pemahaman ibadah yang sejati akan terlihat dari karakter remaja. Karakter merupakan pancaran dari iman yang dimiliki remaja. Judith Allen (2003:60) berpendapat tentang keberadaan remaja "kebanyakan bernada negatif seperti berandalan, pemberontak, pengacau, pecandu obat bius, liar atau ada jurang pemisah generasi namun hal itu tidak tepat.” Kalau remaja mengaku beriman kepada Tuhan di dalam Yesus Kristus, perangai itu akan dapat diubahkan. Berbagai macam hal akan terlihat dari kepribadian si remaja seperti kejujuran, kedisiplinan, keuletan, keramahan, kesabaran, kepedulian, pertanggungjawaban, integritas. Pemahaman ibadah yang sejati bagi kehidupan remaja menjadi sangat penting karena hal ini merupakan tolok ukur atau standar moral dan etika pada saat remaja menjalani hidup. Ibadah dalam pengertian secara umum merupakan sebuah perwujudan ketaatan manusia kepada Tuhan.

Namun adakalanya remaja tidak memahami esensi dari ibadah. Ada banyak faktor yang saling berkaitan dalam pemahaman ibadah yang sejati, antara lain karakter, etika dan moral. Sejauhmana seseorang memahami ibadah yang sejati akan tercermin melalui perubahan karakter sehari-hari. Ibadah tidak hanya yang terlihat secara rutinitas, lebih daripada itu yakni hidup yang sudah diubahkan dipersembahkan kepada Tuhan. Gerald O'Collins (1996:174) berpendapat bahwa ibadah kita yang sesungguhnya hanya berpusat pada Kristus saja, sekaligus ibadah 
juga merupakan keikutsertaan dalam tindakan imamat Kristus demi kepentingan kita dan mengajak kita untuk menjadikan kehidupan sehari-hari menjadi persembahan yang hidup. Namun pada kenyataannya bahwa masih banyak remaja yang belum memahaminya.

Roma 12:1-2 merupakan inti kegiatan setiap orang percaya. Oleh karena itu, Yeremia Rim (1994:33) mengatakan "Saya ingin memperingatkan saudara untuk tidak menganggap rendah ibadah, karena ibadah berhubungan langsung dengan roh saudara. Karena pada hakekatnya kehidupan manusia itu terletak pada rohnya, karena manusia itu roh adanya. Oleh karena itu, ibadah saudara harus benar sehingga dapat mencapai atau mengena pada sasarannya."

Kutipan di atas mengindikasikan bahwa ibadah kepada Tuhan harus disertai dengan rasa cukup atau dengan hati yang tenang, maka akan mendapatkan berkat yang besar. Tetapi beribadah bukan untuk mendapat keuntungan.” Ibadah adalah cara berhubungan dengan Allah dengan benar. Dengan memohon, bersyukur, memuliakan, mengaku dosa dan memuji Allah, maka orang beriman berkomunikasi dan bertemu dengan Allah yang hadir bersama umat-Nya. Dengan ibadah umat mengalami kuasa Allah. Oleh karena itu, sangat perlu mengetahui makna dari ibadah yang sejati. Sehingga tidak hanya sebatas rutinitas atau kebiasaan. Tujuan ibadah sejati yang dilakukan oleh orang Kristen bukan untuk mengembangkan citra diri yang lebih baik, mencapai prestasi atau menemukan peneguhan diri maupun mengembangkan kualitas individu yang membuat seseorang menjadi orang kudus yang paling menonjol. Tetapi untuk mengembangkan kualitas yang memampukan diri hidup secara bertanggung jawab di hadapan Sang Pencipta.

Nilai-nilai ibadah harus didasarkan pada sifat Allah sendiri yakni kudus, berkenan dan sempurna. Tanpa ketiga prinsip ini maka tidak mungkin melakukan ibadah yang sesuai dengan kehendak Allah. Nilai-nilai kebajikan dari ibadah akan menjadi paling berarti jika dijalani dalam pemahaman yang benar. Karena kehidupan dalam ibadah pada dasarnya adalah kehidupan dalam hubungan yang ditentukan polanya dan dipelihara oleh Tuhan. Realitas utamanya adalah hubungan pribadi dengan Tuhan. Simon Chan (2002:144) berpendapat "pemahaman terhadap ibadah yang benar akan mengangkat jiwa sampai pada 
ketinggian penyembahan." Tetapi pada kenyataannya, peneliti melihat masih banyak remaja yang kurang memahami ibadah yang sejati berdasarkan Roma 12:1-2. Sehingga banyak remaja yang tidak memiliki minat bahkan ketertarikan untuk mengikuti ibadah.

Selain faktor dari remaja itu sendiri, orangtua juga mengambil peranan yang sangat penting. Orangtua yang dimaksud adalah keluarga Kristen yang sehat. Sejak awal penciptaan, Allah menginginkan sebuah keluarga sehingga Dia menciptakan kita untuk menjadi bagian di dalamnya. Ini merupakan tujuan Allah bagi kehidupan orang percaya, yang direncanakan jauh sebelum lahir ke dunia ini. Keseluruhan Alkitab merupakan kisah mengenai Allah membangun sebuah keluarga yang akan mengasihi-Nya. Dan didalam keluarga tersebut, Allah memberkati dengan mempercayakan anak-anak kepada keluarga. Jadi sangatlah penting memiliki kehidupan keluarga yang baik, yang berjalan sesuai dengan prinsip Allah. Namun, banyak juga keluarga yang tidak mendasari kehidupan keluarga didalam firman Tuhan. Akibatnya banyak keluarga Kristen yang gagal membina keluarga. Sesungguhnya remaja sangat membutuhkan peranan keluarga sebagai pembina dalam perjalanan hidupnya. Remaja sangat mengharapkan keluarga yang mengandalkan Tuhan. Tetapi pada kenyataannya masih banyak keluarga-keluarga Kristen yang belum berperan secara maksimal.

Ada banyak keluarga yang belum melaksanakan pembinaan rohani di rumah terhadap anak remaja mereka. Bagaimana tidak, masih banyak orang tua khususnya kaum bapak yang gemar bermain di warung-warung tuak sampai larut malam. Sehingga tidak memiliki waktu untuk sekedar bertukar pikiran bahkan bertanya tentang apa yang sedang terjadi pada anak remaja. Atau bahkan para ibu yang senang bercerita sampai tidak mengenal waktu dengan para tetangga sehingga kebutuhan rohani anak remaja terabaikan. Atau menemukan orang tua yang tidak pernah duduk bersama memperhatikan perkembangan kerohanian anak remaja mereka. Ini merupakan kenyataan yang sangat memperihatinkan. B.S.Sidjabat (2008:245) berpendapat "Pembinaan anak khususnya di masa remaja membutuhkan pemahaman yang lebih dalam dan luas bagi orang tua. Jika orangtua mengasihi anak-anak mereka, mereka harus rela menambah wawasan dan cakrawala mereka mengenai perubahan diri anak remaja bertambah. Untuk 
membawa pembaruan dalam generasi penerus, orang tualah yang terlebih dahulu harus memahani perubahan. Sulit untuk mengharapkan perubahan pada diri orang yang kita asuh dan didik jika keteladana perubahan hidup tidak terjadi."

Berdasarkan kutipan di atas bahwa pembinaan rohani yang dilakukan orang tua di rumah sangat menentukan siapa anak itu kelak. Apalagi jika mengingat bahwa memiliki kualitas ibadah yang maksimal tidak hanya sebatas teori saja. Tetapi perlu suatu tindakan nyata yang harus dilakukan orang tua. Diharapkan agar orangtua-orangtua Kristen semakin memperhatikan pembinaan rohani di rumah masing-masing.

Selanjutnya, banyak juga orangtua-orangtua yang tidak memperlengkapi diri dengan pengetahuan dan wawasan yang luas agar dapat mengajarkan makna ibadah dengan benar. Hal ini bisa terjadi karena orangtua yang tidak suka belajar Alkitab. Banyak orangtua yang malas belajar Alkitab. Akibatnya orang tua tidak memiliki wawasan atau pengetahuan untuk menjelaskan makna ibadah yang sejati. Bagaimana mungkin remaja memiliki pemahaman yang benar jika orangtua saja tidak pernah mengajarkannya di rumah. Orangtua yang tidak memiliki wawasan tentang ibadah yang sejati tersebut mengakibatkan pemahaman remaja yang tidak benar. Peneliti menemukan banyak remaja yang bermain-main dalam mengikuti ibadah. Inti ibadah yang sesungguhnya yakni mengalami perjumpaan secara pribadi dengan Tuhan tidak dialami remaja.

Cerminan ibadah yang sejati dalam Roma 12:1-2 seharusnya membuka cakrawala pemahaman orang tua bahwa ibadah dalam bentuk apa pun tidaklah sebatas kegiatan-kegiatan gereja yang berwujud pada ibadah minggu atau ibadahibadah yang lain dalam gereja. Akan tetapi semua kegiatan rohani dapat menjadi wadah remaja bertumbuh secara rohani. Namun wawasan atau cakrawala perwujudan ibadah itu belum banyak ditemukan dalam keluarga-keluarga Kristen. Masih banyak remaja yang tidak memiliki pemahaman yang benar terhadap ibadah tersebut. Sebagai kelanjutan dari pemahaman yang tidak diterima dari keluarga, akibatnya banyak remaja yang melakukan ibadah dengan tidak sungguhsungguh. Bahkan ada sebagian remaja yang datang ke gereja hanya karena faktor sungkan dengan tetangga atau sekedar mengisi buku ibadah yang diberikan oleh sekolah. Selain itu, fakta di lapangan menunjukkan bahwa masih banyak remaja 
Kristen yang beribadah dengan cara bermain-main. Ini merupakan suatu kondisi yang sangat memprihatinkan.

Berkaitan dengan ibadah yang sejati, maka hal ini tidak bisa lepas dari kualitas kehidupan doa yang dimiliki keluarga. Bahkan buku-buku tentang doa dari setiap sudut yang bisa dipikirkan terus ditulis. Marjorie Thompson (2001:79) berpendapat "Doa amat penting dan tidak terpisahkan dari kehidupan rohani." Karena dengan doa, seseorang memasuki hubungan pribadi dengan Tuhan dan melakukan penguasaan diri dan bertumbuh dalam segala nilai-nilai kebajikan. Bahkan dalam pengertian yang lebih luas, doa mengacu pada sikap fundamental orang Kristen terhadap Allah dan hubungannya secara pribadi dengan Allah. Seluruh kehidupan orang Kristen dapat digambarkan sebagai kehidupan doa. Senada dengan hal ini, H.C. Brown (2005:18) berpendapat bahwa manusia memiliki kebutuhan akan hal beribadah, orang Kristen perlu berdoa, belajar Alkitab, berbakti dan mengasihi Allah." Jika doa merupakan jiwa kehidupan rohani Kristen, doa juga harus menjadi pusat kerohanian keluarga. Marthin Luther mengatakan seperti yang dikutip Marjorie bahwa: "saya mempunyai terlalu banyak urusan yang tidak bisa terselesaikan tanpa meluangkan waktu tiga jam setiap hari untuk berdoa". Pernyataan ini memberi pengertian bahwa doa pribadi setiap anggota keluarga amat penting bagi keseluruhan hidup kerohanian keluarga sebab hal itu menambah hubungan dengan Tuhan dan juga anggota keluarga satu dengan yang lain. Sama seperti hubungan manusia yang bertumbuh menuju tingkat yang lebih besar dalam kasih, kepercayaan, komitmen dan sebagainya, hubungan dengan Allah tumbuh secara serupa. Dalam hubungannya dengan doa, bahwa diduga masih banyak keluarga-keluarga Kristen yang belum memiliki mezbah doa dalam keluarga. Dan hal ini sangat bertolak belakang dengan prinsip pelaksanaan tugas dan tanggungjawab orang tua terhadap anak. Dimana orang tua seharusnya mengaktifkan mezbah keluarga yang memiliki ruang lingkup yang sangat luas yakni membawa anak kepada Yesus Kristus agar percaya kepada-Nya atau membimbing mereka mengenal Allah, tahu dan rajin berdoa, gemar membaca Alkitab dan berusaha memahaminya, berdisiplin dan hidup tertib serta bertanggungjawab. Jadi pembinaan yang dilakukan di dalam keluarga menjadi dasar pertumbuhan rohani anak. 
Sudah sejak berabad-abad yang lalu perhatian terhadap kehidupan remaja telah menjadi sorotan, sedikitnya dari sudut perkembangannya agar bisa mempengaruhi kehidupan remaja ke arah yang baik dan benar. Sangat dibutuhkan peranan keluarga yang mampu menjadi figur bagi remaja baik ayah, ibu atau kakak tetapi secara khusus orang tua. Singgih D. Gunarsa (2007:13) menyatakan "Jangan kiranya keluarga hanya merupakan keluarga bagi masyarakat luar akan tetapi keluarganya sendiri tidak merasa aman dan nyaman. Remaja selayaknya harus tumbuh dan berkembang menjadi manusia dewasa yang dapat mengurus dirinya sendiri dan tidak bergantung pada keluarga atau masyarakat. Namun di abad pertengahan ini segi moral dan pendidikan keagamaan bisa menjadi pusat perhatian dan bahkan tujuan pendidikan secara umum, disamping pendidikan formal yang diperoleh untuk menambah pengetahuan dan ketrampilan, supaya mereka mampu kompetitif menjalani kehidupan ini. Pandangan terhadap anak remaja sebagai pribadi yang masih bersih dan polos, jauh dari unsur-unsur yang mendorong kepada perbuatan-perbuatan dosa dan tidak bermoral, sedikit banyak dipengaruhi oleh peran agama di abad pertengahan itu. Permasalahan yang muncul diduga bahwa orang tua belum mampu menjadi figur atau teladan yang layak ditiru oleh anak. Artinya perkataan dan pengajaran orang tua perlu sepadan termasuk harmonisnya hubungan suami dan istri. Seperti yang diungkapkan oleh B.S.Sidjabat (2008:152) berpendapat bahwa pemahaman anak tentang kasih sayang Tuhan dialami dari kehangatan kasih sayang ayah dan ibunya. Jadi kesepakatan kedua orang tua sangat perlu dalam rangka menerapkan disiplin dan hukuman yang tepat atas pelanggarannya. Dan disiplin dalam keluarga harus diterapkan di atas aturan yang jelas dan realistis.

Walaupun remaja mendapatkan pembinaan-pembinaan di sekolah, gereja dan masyarakat namun lingkungan keluarga merupakan faktor primer bagi pertumbuhan kerohanian remaja. Orang tua berperan aktif baik sebagai pendidik, guru, pemimpin, sahabat, pendamping, imam, model dan banyak lagi. Pada dasarnya sekolah dan gereja hanya merupakan rekan (partner) orang tua dalam mendidikan dan mencerdaskan anak mereka. Sekalipun demikian, sekolah tentunya memiliki andil yang besar juga bagi pengembangan karakter remaja disamping peningkatan pengetahuan, sikap dan keterampilannya. Ada banyak 
dampak sekolah bagi remaja baik melalui pelajaran yang diterima maupun keteladanan hidup dan pola relasional dan kualitas interaksi guru dengan anak didiknya. Dan suasana komunitas anak di sekolah yang kondusif juga sangat membantu pengembangan karakter anak yang sehat. Namun, bertolak belakang situasi ini, justru sebaliknya banyak orang tua Kristen memiliki paradigma bahwa kebutuhan rohani anak adalah tugas dan tanggungjawab sekolah dan gereja. Permasalahan yang muncul diduga bahwa orang tua kurang memiliki tanggungjawab terhadap kebutuhan rohani anak sehingga remaja cenderung mencari kebebasan di luar rumah.

Pembinaan anak khususnya di masa remaja membutuhkan pemahaman yang lebih dalam dan luas bagi orang tua. Marjorie (2001:18) berpendapat bahwa "Gereja secara konsisten mempertahankan agar pendidikan agama dimulai dari rumah dimana anak-anak mepunyai kemampuan untuk meniru orang tua mereka dan ikut serta dalam peribadahan keluarga dan gereja. Semua bentuk pendidikan lainnya hanyalah sebagai bentuk pelengkap bagi pembentukan dasar iman ini. Warisan ajaran Kristen-Yahudi menyatakan bahwa orangtua mempunyai tanggungjawab utama mendidik anak-anak mereka dalam iman. Ini adalah tanggungjawab istimewa."

Jika orang tua mengasihi anak-anaknya mereka harus rela menambah wawasan agar cakrawala mereka mengenai perubahan diri anak remaja bertambah. Mereka pun harus bersedia mendengar nasihat-nasihat ahli pembinaan remaja. Dan bertukar pikiran di antara orang tua yang memiliki anak remaja menjadi sangat penting. Secara khusus dalam menegakkan disiplin secara konsisten supaya anak mentaati aturan. Pendekatan yang digunakan sebaiknya jangan otoriter atau penunjukan kuasa. Sebaliknya, orang tua jangan mengemis kepada anak agar mereka patuh. Oleh karena itu, orang tua harus tegar, teguh pada prinsip, tahu apa yang benar dan bagaimana seharusnya bersikap dan bertindak benar. Aturan harus dikomunikasikan kepada anak dan semua pihak anggota keluarga mematuhinya. Kalau anak mematuhi aturan, orang tua jangan enggan memberikan pujian. Sebaliknya, jika anak melanggar aturan orang tua harus menegakkan sanksi tanpa harus memukul secara fisik. Tepukan penuh kasih sayang dari ayah di bahu anak remajanya juga sudah cukup bermakna 
menguatkan apa yang dikomunikasikan. Namun pada kenyataannya, tidak semua orang tua berpikir demikian. Masih banyak ditemui orang tua yang bertindak anarkis dan otoriter dan tidak konsisten dalam menerapkan aturan. Marjorie J. Thompson (2001:13) berpendapat "anak-anak belajar dari apa yang mereka jalani dalam kehidupan mereka. Mereka menyerap pengetahuan tentang dunia ini melalui kejadian-kejadian yang mereka alami dan amati. Anak-anak lebih banyak belajar dari perkataan atau nasihat." Dalam hal ini, permasalahan yang muncul diduga orang tua kurang konsisten dalam menegakkan disiplin di rumah sehingga anak cenderung kurang menghargai orang tua. Ketidakkonsistenan orang tua ini juga mengakibatkan semakin pudarnya wibawa dan otoritas orang tua di hadapan anak-anak.

Ketaatan anak mengikuti ibadah dan ajaran di gereja biasanya berkembang karena nasihat dan teladan dari orang tua. Sikap anak kepada Tuhan banyak dipengaruhi dari apa yang dilihat pada kehidupan ayah dan ibunya. Dan ketika anak memasuki remaja, cukup banyak pertanyaan tentang iman dan kerohanian semakin bertumbuh. Daya tarik sikap dan pandangan teman-teman sebaya ikut memberi masukan bagi pertumbuhan rohani remaja. Artinya cukup banyak remaja di gereja menjadi lebih giat di dalam mengikut Tuhan karena dukungan temanteman atau seniornya. Pengajaran yang benar dan jujur dari pimpinan jemaat juga turut menguatkan dukungan para sahabatnya. Dan bahkan sebagian remaja lanjut sudah mampu memiliki cara beriman individu dimana mereka menentukan sikap dan pilihan terhadap apa dan siapa yang dipercayai, yang dibangun atas dasar pengamatan dan pengalaman pribadinya. Namun, realitanya di lapangan bahwa masih banyak remaja yang belum mengalami pertumbuhan kerohanian. Bahkan tidak jarang remaja yang memilih pindah keyakinan, beralih pada sekte atau pemujaan baru karena pengaruh rekan-rekan atau sahabat dekat yang dimilikinya. Mengapa hal ini bisa terjadi? Ini sekaligus menjadi pertanyaan penting dan pukulan bagi para orang tua Kristen dan pembina-pembina remaja. Dalam hal ini, remaja sangat perlu diajarkan banyak firman Tuhan terutama mengenai harga mengikut Kristus.

Namun fenomena yang terjadi melukiskan bahwa pemahaman ibadah yang sejati berdasarkan Roma 12:1-2 kurang mengakar sehingga kurang berpengaruh 
bagi pertumbuhan kerohanian remaja. Melalui hal ini, penulis menganalisa sejauhmana pemahaman ibadah yang sejati berdasarkan Roma 12:1-2. Dan yang menjadi rumusan masalah adalah pertama, seberapa besar pemahaman ibadah yang sejati berdasarkan Roma 12:1-2 di GPPS Maranatha Diski? Kedua, seberapa besar pertumbuhan kerohanian remaja di GPPS Maranatha Diski? Ketiga, seberapa besar pengaruh pemahaman ibadah yang sejati berdasarkan Roma 12:1-2 terhadap pertumbuhan kerohanian remaja di GPPS Maranatha Diski? Sedangkan tujuan penelitian ini adalah untuk mengetahui seberapa besar tingkat pemahaman tentang ibadah yang sejati berdasarkan Roma 12:1-2, untuk mengetahui seberapa besar tingkat pertumbuhan kerohanian remaja dan untuk mengetahui seberapa besar pengaruh pemahaman ibadah yang sejati berdasarkan Roma 12:1-2 terhadap pertumbuhan kerohanian remaja di GPPS Maranatha Diski?

Pemahaman adalah proses, cara atau perbuatan dalam memahami suatu obyek. Atau dapat juga berarti mengerti secara tepat tentang sesuatu dan dapat mengaplikasikan pengertian tersebut dalam tindakan yang sesuai dengan makna asli yang terkandung dalam obyek yang dipahami. Ibadah adalah perbuatan untuk menyatakan bakti kepada Allah yang didasari ketaatan mengerjakan perintah-Nya dan menjauhi larangan-Nya. Poerdarminta (1984:367) berpendapat "ibadah adalah kebaktian kepada Tuhan, perbuatan dan seterusnya untuk menyatakan bakti kepada Tuhan. Beribadah artinya menunaikan segala kewajiban yang diperintahkan oleh agama dengan sungguh-sungguh." Dalam bahasa Inggris diterjemahkan dengan kata worship atau service. Kedua kata ini berasal dari bahasa Ibrani Avoda dan bahasa Yunani Latreia yang kedua-duanya ditujukan kepada pelayanan budak belian atau upahan dalam melakukan pekerjaannya bagi majikannya. Dalam rangka menjalankan pelayanan ini, para budak akan bersikap hormat atau taat yang ditunjukkan dengan posisi membungkuk atau tiarap. Corner (2001:61) berpendaat “apabila ditujukan kepada Tuhan, maka maknanya lebih kepada pengungkapan rasa hormat, takut yang dituangkan seluruhnya dalam melakukan apapun yang diperintahkan Allah yang dalam terminologi teologi disebut ibadah.

Dalam ibadah manusia menyembah Allah, memuliakan dan mengucap syukur. Yeremia Rim (1994:33) menuliskan: "Saya ingin memperingatkan 
saudara untuk tidak menganggap rendah ibadah, karena ibadah berhubungan langsung dengan roh saudara. Karena pada hakekatnya kehidupan manusia itu terletak pada rohnya, karena manusia itu roh adanya. Oleh karena itu, ibadah saudara harus benar sehingga dapat mencapai atau mengena pada sasarannya."

Dengan demikian Allah adalah pusat ibadah. Dan manusia beribadah adalah sebagai respon dalam ucapan syukur kepada karya Allah dalam hidup manusia. Sedangkan sejati memiliki arti tulen, sungguh, asli, murni. Apabila dihubungkan dengan ibadah yang sejati, maka terangkailah sebuah pengertian bahwa ibadah yang sejati adalah respon manusia kepada karya Allah yang didasari ketaatan mengerjakan perintah-Nya dan menjauhi larangan-Nya secara sungguh-sungguh.

Makna ibadah yang sejati yang terkandung dalam Roma 12:1-2 adalah mempersembahkan tubuh sebagai persembahan yang hidup, kudus dan berkenan kepada Allah. Bahasa yang dipakai di sini diambil dari Perjanjian Lama dan mengingatkan bahwa orang-orang percaya Yahudi memberikan persembahan kurban kepada Tuhan. Tetapi orang-orang Kristen, harus mempersembahkan tubuh mereka sendiri kepada Allah sebagai kurban yang hidup, kudus dan berkenan. Yang dimaksud adalah suatu pelayanan rohani yang melibatkan seluruh kemampuan mereka. Bahkan Roma 12:1 berisi nasihat Paulus tentang tata cara tingkah laku sebagai anggota jemaat Kristen. Kurban itu harus bersifat sempurna. Dari penelusuran tersebut dapat ditarik kesimpulan bahwa dalam Roma 12:1-2 rasul Paulus hendak meyakinkan jemaat di Roma dengan memberikan asas-asas teologi bagaimana dapat menjadi benar dan tetap dalam kebenaran di hadapan Allah. R. A. Jaffray (2007:210) berpendapat bahwa "Roma 12 adalah rangkaian kelima yang seakan-akan merupakan puncak dari segala pengajaran Paulus. Dave Hagelberg juga (2007:234) berpendapat bahwa dalam pasal ini, dasar dari dorongan dan nasehat bahkan peringatan Paulus adalah kemurahan Allah, bukan berdasarkan ancaman seperti ancaman hukuman kekal atau nasehat yang didorong dari kuasa kebencian. Dorongan kasih itu secara nyata terlihat dalam sebutan "saudara-saudara". Paulus menggunakan sebutan ini untuk menunjukkan bahwa jemaat non-Yahudi berada pada posisi yang sama dengan dirinya di hadapan Allah. Jadi berbicara mengenai amanat rasul Paulus kepada jemaat di Roma tentang ibadah yang sangat penting bahwa ibadah yang sejati adalah menyerahkan 
seluruh kehidupan secara total sebagai persembahan yang hidup, kudus dan berkenan. Allah tidak hanya menginginkan korban atau pemberian tetapi hidup yang sesungguhnya secara utuh setiap saat.

Kata yang kedua adalah tubuh yang berarti bagian yang hidup. Maksudnya tentu bukan menyerahkan tubuh untuk dibunuh atau menyiksa diri. Melainkan seperti yang diungkapkan oleh Collin Brown (1971:234) bahwa mempersembahkan tubuh sangat berkaitan erat dengan tindakan memberikan atau menyerahkan tubuh itu sendiri. Sedangkan hidup berarti masih terus ada, bergerak sebagaimana mestinya; masih tetap ada, tidak hilang. Hampir semua versi menggunakan kata yang sama yaitu living. Jadi secara hurufiah, hidup berarti yang masih tetap ada.

Pengertian kata tubuh (your bodies) yang menjadi korban yang dipersembahkan sama artinya dengan kata 'dirimu sendiri (yourselves). Kemungkinan Paulus menggunakan kata ini tidak hanya berbicara secara desain yaitu tubuh secara harafiah, tetapi juga secara keseluruhan yaitu tubuh, jiwa dan roh yang diserahkan sebagai persembahan kepada Allah. Tubuh yang dimaksud bukanlah dalam arti harafiah yaitu mempersembahkan tubuhnya dengan cara membunuh tubuhnya, seperti yang dilakukan beberapa agama lain dalam ritual keagamaan mereka. Bukan juga sebuah tuntutan untuk menyiksa tubuhnya agar dapat hidup lebih kudus dengan bertapa, berpuasa seperti yang dilakukan kaum asketis. Bukan juga mempersembahkan tubuh dengan hidup sebagai martir demi mempertahankan iman percayanya.

Kata persembahan yang dimaksud bukanlah seperti korban persembahan yang diletakkan di atas altar, tetapi mempersembahkan keseluruhan dirnya tanpa ada cacat dalam pelayanan. Penafsiran ini didasarkan pada pemakaian kata "itulah ibadahmu yang sejati'. Kata ibadah yang dipakai adalah latreian bukanlah persembahan (offering) melainkan penyembahan (worship). Jadi bukan kepada sesuatu atau benda yang dipersembahkan, tetapi kepada esensi dari penyembahan. Suatu pelayanan yang sesuai dengan kehendak Allah. Wiersbe (2007:137) berpendapat ibadah yang sejati adalah tiap-tiap hari merupakan suatu pengalaman ibadah bila tubuh anda diserahkan kepada Tuhan. Jadi, jika pengertiannya dirangkai maka yang dimaksud dengan persembahan yang hidup adalah 
mempersembahkan seluruh pikiran, perasaan, perbuatan dan perkataan untuk memuliakan Kristus.

Gleason L. Archer (2004:672) berpendapat "kehidupan yang telah diubah secara terus-menerus akan menghasilkan buah Roh jika memang penyerahan iman tersebut bukan sekedar kepurak-puraan atau tindakan menipu diri sendiri, dan jika anak Allah yang sejati itu mau selalu menyerahkan tubuhnya sebagai persembahan yang hidup kepada Allah yang menyelamatkan." Kutipan ini mengindikasikan bahwa anak Allah adalah teladan sejati yang telah menyerahkan tubuhnya kepada Allah. Jadi, mempersembahkan tubuh sebagai persembahan yang hidup adalah mempersembahkan seluruh pikiran, perasaan, perbuatan dan perkataan kepada Kristus dalam kehidupan sehari-hari sebagai penerapan dari iman kepada Kristus.

Manusia diciptakan sebagai makhluk yang dapat berpikir dan mengembangkan pemikirannya, ini sekaligus mencerminkan hikmat Allah dan juga membedakan manusia dengan binatang (2Ptr 2:12). Bahkan Adam sebagai manusia pertama telah menggunakan akal budi (pikirannya) dalam kebergantungannya kepada Allah. Pratt juga berpendapat bahwa dari peranan pikiran yang dimiliki manusia sebelum jatuh ke dalam dosa, maka ada beberapa poin penting yang perlu diamati yakni: "Pertama, menggunakan akal budi (pikiran) dan mengembangkan pemikiran itu bukanlah merupakan sesuatu yang jahat atau salah. Kekristenan telah mendapat berbagai macam serangan dari mereka yang mengklaim bahwa segala sesuatu harus "masuk akal" dan "ilmiah". Kedua, logika tidaklah berada di atas fakta perbedaan antara Pencipta dan ciptaan. Pada saat berbicara tentang manusia dalam menggunakan akal budinya atau pikiran, harus diingat bahwa logika hanya merupakan refleksi dari hikmat dan pengetahuan Allah.

Manusia diciptakan sebagai makhluk yang dapat berpikir dan mengembangkan pemikirannya tetapi harus menyadari keterbatasan pemikiran dan kebergantungan pemikirnanya kepada Penciptanya. Hubungannya uraian di atas dengan menyelaraskan pikiran kepada Firman Tuhan bahwa pikiran yang dianugerahkan Tuhan kepada manusia sejak penciptaan sebenarnya sangat baik. 
namun, jika pikiran itu tidak dikuasai oleh Firman Tuhan maka akan bertentangan dengan kehendak Allah.

Dalam Roma 7:23 dan 8:5-7 memperlihatkan bahwa pusat semua ikatan roh adalam pikiran. Disitulah tempat peperangan berlangsung dan dimenangkan jika ingin mengalami kebebasan di dalam Kristus. Seperti yang diungkapkan oleh Neil T. Anderson (1996:61) berpendapat bahwa beberapa benteng dari kebiasaan buruk dan pola pikiran berdosa terbentuk ketika anda berusaha untuk hidup tanpa tergantung pada Allah. Bagaimana memusnahkan kubu itu? Pola pikiran dan tingkah laku negative dipelajari tetapi tidak dapat dipelajari lewat pemahaman Alkitab yang disiplin dan bimbingan. Beberapa kubu tertanam lewat pengaruh iblis dan konflik rohani dari gangguan mental masa lalu dan masa sekarang yang mengikat manusia. Manusia perlu dibebaskan dari belenggu tipuan iblis lewat kebenaran Firman Allah.

Ibadah yang sejati dengan mempersembahkan tubuh sebagai persembahan yang hidup memiliki pengertian bahwa seluruh pikiran harus selaras atau cocok dengan Firman Tuhan. Kecocokan ini akan terlihat pada diri remaja bila hal-hal yang sesuai dengan Firman Tuhan yang menjadi kesukaannya. Pikiran yang selaras dengan Firman Tuhan akan ditandai dengan kesukaan untuk memikirkan hal-hal rohani. Artinya tidak memikirkan hal yang sia-sia. Dan juga kesukaannya memikirkan hal-hal yang simpel atau sederhana. Sederhana yang dimaksud adalah tidak melebihi apa yang mampu dipikirkan. Dan yang terakhir adalah tidak memikirkan apa kata orang artinya jika sungguh-sungguh ingin beribadah, maka apa pun yang terjadi akan tetap beribadah dengan sungguh-sungguh.

Pengendalian diri atas perasaan bukanlah tujuan akhir. Namun ada hal yang perlu dipahami dibalik pentingnya pengendalian diri dimana ini menjadi berharga selama hal itu membuat seseorang menjadi orang seperti yang dikehendaki Tuhan. Mengapa? Karena seseorang mungkin sempurna dalam pengendalian diri dan pada saat yang sama juga bobrok dalam hal moral. Jadi penguasaan diri dapat memungkinkan seseorang melakukan kejahatan yang lebih besar dan dapat juga memungkinkan melayani Tuhan dengan lebih berhasil. Kaitannya dengan menyelaraskan perasaan kepada Kristus, bahwa orang yang sungguh-sungguh memaknai ibadah yang sejati dalam hidupnya pasti memiliki pengendalian diri. 
Pengendalian diri yang akan membuat perasaan seseorang selaras dengan Firman Tuhan. Keselarasan ini akan terlihat dalam diri seseorang yang selalu bersukacita, tidak kuatir tentang apapun dan tidak menyimpan rasa dendam. Ketiga hal ini hanya bisa dilakukan jika seseorang sungguh-sungguh beribadah kepada Tuhan.

Pertumbuhan rohani dengan keinginan berbuat sesuatu kepada orang lain secara bersama-sama berakar pada keselarasan perbuatan kepada Firman Tuhan. Orang-orang percaya dalam Kristus diperbaharui menurut sifat mereka yang semula sebagai manusia yang diciptakan menurut gambar Allah. Mereka diberikan kebenaran, kesucian dan pengetahuan yang benar tetapi semua itu telah hilang pada saat kejatuhan. Perbuatan yang selaras dengan Firman Tuhan berarti bahwa apa saja yang dilakukan cocok dengan Firman Tuhan. Artinya tingkah laku yang ditunjukkan dalam hidup sehari-hari adalah tindakan yang tidak bertentangan dengan Firman Tuhan. Jadi hubungannya dengan ibadah yang sejati, bahwa orang yang sungguh-sungguh beribadah kepada Tuhan adalah mereka yang menuruti perintah orang tua, yang rajin membantu pekerjaan sehari-hari di rumah dan yang perbuatannya tidak usil.

Selanjutnya persembahan yang kudus. Secara hurufiah kata kudus berarti suci, murni, terhindar dari kejatan, dikhususkan untuk tujuan Allah. Tidak ada versi yang memakai istilah lain selain kudus. Ini merupakan kelanjutan dari frasa sebelumnya yakni tentang persembahan yang hidup. Konteks ayat ini adalah sehubungan dengan perintah agar memberikan tubuh menjadi pengorbanan yang suci, murni, yang tidak bercacat. Dalam tata bahasa Indonesia, kudus adalah kata sifat yang memiliki arti segala sesuatu yang terpisahkan (dikhususkan) dari kebiasaan atau hal-hal yang duniawi untuk diserahkan kepada Allah. Bahasa Yunani kudus merupakan kata sifat yang memiliki bentuk akusatif feminin tunggal yang memiliki arti terpisah dari kondisi umum atau dikhususkan. Fungsi akusatif pada kata ini disebut sebagai pembatasan artinya memberi batas akhir pada suatu tindakan atau dapat juga disebut sebagai penderita atau obyek langsung. Dengan demikian tubuh bukan lagi milik sendiri sebab telah dikhususkan menjadi persembahan atau kurban dan diserahkan menjadi milik Allah. Jadi kudus artinya dipisahkan dan dikhususkan kepada Allah. 
Dalam kaitannya dengan persembahan yang kudus, maka kehidupan remaja seharusnya tidak terjerumus dalam pergaulan seks. Seks adalah bagian yang diberikan Allah bagi sistem syaraf otonomi manusia. Seks yang normal berfungsi sebagai bagian yang tertur dan berirama dalam hidup. Namun sejak manusia berkecimpung dalam lautan dosa, sejak saat itulah kisah tentang seks tidak putusputusnya. Manusia diliputi rasa ingin tahu yang sangat besar yang perlu dipuaskan. Bahkan segala sesuatu yang terlarang tampaknya semakin menimbulkan tantangan dan rasa ingin tahu. Semakin mendalam rasa ingin tahu, semakin sulit melepaskan diri dari dalamnya.

Secara biologis, manusia mempunyai dua jenis dorongan yaitu dorongan makan untuk mempertahankan kehidupan dan dorongan seksual untuk melanjutkan kehidupan di dunia ini. Mereka yang bertitik tolak dari dorongan makan berpendapat betapa bahayanya kalau dorongan itu tidak dihiraukan atau dilalaikan, diabaikan atau ditekan. Tidak makan pada saatnya bukannya menguntungkan malahan merugikan manusia. Demikian juga dengan pandangan tentang dorongan biologis seksual, kalau tidak dilayani, manusia dirugikan. Namun pandangan ini jelas tidak dapat diterima kebenarannya. Mengapa? Karena kedua dorongan baik makan dan seks itu tidak identik atau mirip dalam segala aspek-aspeknya. Jika dilihat dari sudut fisiologi, free sex sangat merugikan karena mengabaikan bahwa manusia dalam dimensi fisik dan mental atau spiritualnya merupakan satu kesatuan yang utuh.

Persetubuhan menuntut suatu keterlibatan total dan merupakan suatu penyerahan total yang mencakup keseluruhan kepribadian seseorang. Artinya manusia sebagai ciptaan moral dengan nilai kesetiaan dan tanggungjawab sebagai nilai utama justru membutuhkan hubungan yang bertanggungjawab dan setia. Karena perbuatan free sex tidak berdasarkan satu ikatan batin maka free sex mengurangi martabat manusia. Mengapa? Karena tubuh manusia dengan segala potensinya dipilih Allah sebagai tempat kediaman-Nya di bumi. Tubuh itu dimaksudkan agar menjadi rumah kediaman Roh Kudus.

Dimensi mental dan jasmani tidak dapat dipisahkan. Apa yang terjadi pada tubuh mengakibatkan hal-hal positif atau negatif terhadap seluruh eksistensi hidup seseorang. Bagaimana tidak, akibat yang ditimbulkan karena melakukan 
hubungan sebelum menikah atau free sex bagi para wanita adalah rasa kecewa, rasa terluka, malu dan tertipu dan rasa bersalah yang berpotensi membahayakan jiwanya jika tidak segera ditolong. Sedangkan bagi pria, dia juga tidak terbebas dari beban mental. Lambat laun si pria akan kehilangan harga diri dengan segala akibatnya. Pria akan menyadari bahwa ia tidak dapat dipercaya, ia juga dikuasai oleh emosi dan keakuan yang menyebabkan rasa bimbang.

Sedangkan dari sudut sosiologi, orang-orang yang melakukan free seks akan mengalami perubahan yang besar baik dalam sikap maupun tindakannnya kepada lawan jenis. Hubungan antara kedua belah pihak akan berubah dari hubungan yang wajar atau normal menjadi tidak wajar atau tidak normal. Bahkan keduanya akan kehilangan rasa hormat satu dengan yang lain karena mereka memandang satu dengan yang lain sebagai alat pemuas nafsu. Dan akhirnya akan diliputi rasa curiga, cemas, kwatir, bimbang dan tidak lagi percaya. Oleh karena itu, jika ditinjau dari sudut manapun free sex harus ditolak karena karya Allah dirugikan dan dirusak. Jadi, remaja yang sungguh beribadah kepada Tuhan adalah mereka yang percaya tidak boleh melakukan hubungan sex sebelum menikah. John Stott (1993:430) berpendapat "ada tiga hal dalam hubungan dengan seks dan pernikahan dalam Alkitab: Pertama, kebutuhan manusia akan seorang kawan (tidak baik kalau manusia itu seorang diri saja); kedua, upaya ilahi untuk memenuhi kebutuhan insani ini (kebutuhan akan partner, mitra dan pasangan); dan ketiga, lembaga pernikahan sebagai pencipta perempuan (menjadi sedaging... persetubuhan heteroseksual dalam perkawinan adalah lebih dari penyatuan).

Selain menolak seks sebelum menikah, mereka juga percaya menolak homo dan lesbian. Karena Alkitab jelas mengatakan: "Janganlah engkau tidur dengan laki-laki secara orang bersetubuh dengan perempuan, karena itu suatu kekejian bagi Tuhan" (Im 18:22). "Jika seorang laki-laki tidur dengan laki-laki secara orang bersetubuh dengn perempuan, jadi keduanya melakukan suatu kekejian, pastilah mereka dihukum mati dan darah mereka tertimpa pada mereka sendiri" (Im 20:13). Sedangkan dalam Perjanjian Baru, Yesus menanggapi demikian, Jawab Yesus: Tidakkah kamu baca, bahwa Ia yang mencipatakan manusia sejak semula menjadikan mereka laki-laki dan perempuan? Dan firman-Nya: sebab itu seorang laki-laki akan meninggalkan ayah dan ibunya dan bersatu dengan dengan 
istrinya dan keduanya menjadi satu daging. Demikianlah mereka bukan lagi dua melainkan satu. Karena itu, apa yang telah dipersatukan Allah tidak boleh diceraikan manusia (Mat 19:4-6).

Seperti yang diungkapkan oleh William Consiglio: Allah tidak pernah menciptakan seseorang menjadi homoseks; Ia juga tidak menciptakan gen-gen, hormone-hormon atau sifat-sifat biologi seseorang sebagai homoseks atau lesbi. Allah menciptakan setiap orang dengan sifat heteroseksual. Saya dapat mengenali faktor-faktor tertentu yang mungkin memberi kecenderungan kepada seseorang sehingga mengalami gangguan emosi seperti cacat bawaan namun tidak satu pun diantaranya yang menyebabkan homoseksualitas. Bagi Yesus, alternatif lain mengenai kegiatan seksual hanyalah kehidupan bertarak dengan disiplin pribadi. Bahkan dalam Roma 1:27 Rasul Paulus menghubungkan perilaku jinah dan gay sebagai kesesatan demikian juga dengan kegiatan onani dan masturbasi. Jadi bagi Paulus, perilaku hubungan homoseksual (pemburit) sama salahnya dengan penyembahan berhala dan zinah, yang tidak layak meneriman bagian dalam Kerajaan Allah.

Selain seks, remaja juga harus menghindari narkoba. Rokok adalah silinder dari kertas berukuran panjang antara 70 hingga $120 \mathrm{~mm}$ (bervariasi tergantung negara) dengan diameter sekitar $10 \mathrm{~mm}$ yang berisi daun-daun tembakau yang telah dicacah. Rokok dibakar pada salah satu ujungnya dan dibiarkan membara agar asapnya dapat dihirup lewat mulut pada ujung lain. Rokok mengandung kurang lebih 4000 lebih elemen-elemen dan setidaknya 200 diantaranya berbahaya bagi kesehatan. Racun utama pada rokok adalah tar, nikotin, dan karbon monoksida. Dan penyakit yang ditimbulkan oleh rokok adalah paru-paru, jantung, emfisema, dan lebih cepat tua.Selain rokok, remaja juga mengenal narkotika dan obat-obat terlarang lainnya merupakan golongan obat bius. Bahkan akhir-akhir ini jenis ectasy dan putauw semakin popular dan dibicarakan di suratsurat kabar. Bahkan narkoba ini bukan hanya manjadi masalah dengan dunia disko atau club-club malam namun telah melibatkan segenap lapisan masyarakat termasuk artis, pilot, kepolisian, bahkan kalangan agama. Candu sebagai musuh masyarakat memang disadari dapat merusak mental dan jiwa tetapi penggunaannya tidak mudah dihentikan karena berkaitan dengan untung yang luar 
biasa besar dari penjualan narkoba ini. Kenyataan ini sebenarnya menjadi malapetaka bagi anak remaja. Ecstasy dan putauw suda mulai mengancam remaja karena kalangan ini yang paling banyak menjadi korban jerat ectasy dan putauw.

Namun hal itu tidak menjadi alasan terperangkap kedalamnya. Gereja sebagai persekutuan orang-orang percaya pelu secara aktif ikut berperan serta dalam penanggulangannya. Selain itu, remaja Kristen yang sungguh-sungguh beribadah kepada Tuhan harus berani berkata tidak pada narkoba, tidak pada rokok dan tidak pada minuman keras. Berbekal kehidupan yang telah diperbaharui dan dimerdekakan, remaja Kristen adalah ciptaan Allah dan menurut gambar-Nya yang harus hidup sesuai dengan standar itu. Dan salah satu cara memuliakan Allah adalah dengan meninggalkan perbuatan daging dan hidup di dalam Roh Kudus. Dan berdoa dengan sungguh-sungguh agar tetap mampu mempersembahkan tubuh sebagai persembahan yang hidup, kudus dan berkenak kepada Allah.

Sehingga remaja yang sungguh-sungguh beribadah kepada Tuhan adalah remaja yang tidak tertarik pada gambar-gambar porno, karena masih banyak buku-buku rohani yang dapat dibaca sehingga pemahaman akan Firman Tuhan semakin baik. remaja juga tidak tertarik kepada situs-situs porno. Semakin mudahnya akses internet akan membawa dampak yang buruk jika tidak berpegang pada Firman Tuhan. Tetapi internet akan digunakan dengan hal-hal yang positif. Selain itu, remaja yang beribadah dengan sungguh-sungguh kepada Tuhan juga tidak akan tertarik dengan film-film porno.

Frasa persembahan yang berkenan dapat dimengerti yang memuaskan Allah. Secara hurufiah kata "persembahan berkenan" dapat berarti menyenangkan Allah, berkenan kepada Allah, memuaskan bagi Allah.

Makna frasa persembahan yang berkenan dalam prinsip kontekstual tidaklah terpisah jauh dari frasa-frasa sebelumnya yang berhubungan dengan esensi ibadah yang sesungguhnya yakni memuaskan bagi Allah yang merupakan suatu tindakan yang lebih spesifik dibanding dengan kata sebelumnya yaitu hidup dan kudus. Kalau hidup dan kudus lebih berpengertian umum tentang tindakan seseorang dalam melakukan ibadah yang sejati. Tetapi memuaskan bagi Allah sudah sampai pada tingkat berikutnya dimana Allah menerima persembahan tersebut. 
Memuaskan berasal dari kata dasar puas berarti merasa senang, lega, kenyang dan sebagainya karena sudah merasa secukup-cukupnya atau sudah terpenuhi hasrat hatinya atau lebih dari cukup. Apabila dihubungkan dengan Allah berarti apa yang dipersembahkan itu sudah diterima dan Allah merasa senang karena keinginan hati-Nya terpenuhi.

Secara sederhana menyenangkan hati Allah dapat dipahami sebagai sebuah dampak dari persembahan yang memuaskan hati Allah, sehingga persembahan itu naik di hadapan Tuhan dan menyenangkan hati Allah. Kata ini bertalian dengan klimaks dari persembahan itu, sedang memuaskan bertalian perubahan hidup yang terus menerus. Mendatangkan kegembiraan bagi Allah, hidup bagi kesenangan Allah adalah tujuan utama hidup orang percaya. Jika pemahaman ini dimiliki oleh setiap orang percaya, maka tidak aka nada lagi yang merasa tidak berharga dihadapan Allah. Pengertian ini mengungkapkan betapa orang percaya berharga di mata Allah. Kata ini bertalian dengan pengertian bahwa dari pihak Allah ingin orang percaya memiliki kehidupan yang mendatangkan kesenangan bagi Allah lebih dari apapun. Dan hal-hal yang menyenagkan bagi Allah adalah jika orang percaya tiaphari memuji Tuhan, tiap hari berdoa dan suka membawa korban.

\section{METODE PENELITIAN}

Metode penelitian yang digunakan dalam penelitian ini adalah penelitian kuantitatif dengan metode survei. Disebut survei karena penelitian ini menggunakan populasi langsung menjadi sample yang representatif untuk mengambil kesimpulan dengan menggunakan kuesioner atau angket sebagai pengumpul data. Pengumpulan data dalam penelitian ini dilakukan dengan cara melakukan penelitian lapangan; secara langsung di lokasi penelitian untuk mendapatkan data yang dibutuhkan. Pengumpulan data di lapangan dilakukan dengan menggunakan kuesioner.

\section{HASIL PENELITIAN}

Hipotesis awal adalah kecenderungan pemahaman ibadah yang sejati berdasarkan Roma 12:1-2 adalah kurang paham. Berdasarkan uji statistik yang dilakukan dengan confidence interval pada taraf signifikansi 5\%, dan diperoleh

nilai Lower Bound dan Upper Bound yakni 103.82 s/d 105.46 terletak pada 
kategori cukup paham saja di dalam tabel klas interval. Padahal sebagai seorang jemaat, pemahaman yang benar tentang ibadah yang sejati itu penting dimiliki. Seorang jemaat harus sadar bahwa sebagai jemaat harus memiliki pemahaman bahwa setiap orang percaya harus mengerti makna ibadah yang sejati dimana menyerahkan seluruh pikiran, perasaan, perbuatan, perkataan untuk memuliakan Tuhan.

Hipotesis awal kedua kecenderungan pertumbuhan kerohanian remaja GPPS Maranatha Diski adalah cukup paham. Analisis data dilakukan dengan confidence interval pada taraf signifikansi 5\%, dan diperoleh nilai Lower Bound dan Upper Bound yakni 73.33 s/d 81.15 terletak pada kategori paham di dalam tabel klas interval. Artinya, pertumbuhan kerohanian remaja dalam kategori paham. Kenyataan itu tersebut tidak sesuai dengan hipotesa awal peneliti, tetapi pertumbuhan kerohanian perlu sekali ditingkatkan, karena hal tersebut merupakan hal yang paling mendasar dan hakiki yang harus dimiliki setiap orang agar menyerahkan seluruh hidupnya dipersembahkan kepada Kristus.

Hipotesis awal ketiga adalah kecenderungan pengaruh Pemahaman Ibadah Yang Sejati Berdasarkan Roma 12:1-2 terhadap Pertumbuhan Kerohanian Remaja adalah paham. Dari hasil uji statistik regresi sederhana antara variabel Pemahaman Ibadah Yang Sejati Berdasarkan Roma 12:1-2 (X) terhadap variabel Pertumbuhan Kerohanian Remaja GPPS Maranatha Diski diperoleh hasil temuan nilai $\mathrm{r}_{\mathrm{yx}}$, sebesar 0,178 dan bernilai positif. Yang berarti, besarnya hubungan antara pemahaman ibadah yang sejati terhadap pertumbuhan kerohanian adalah 17,8 \%, maka hubungan antara variabel $\mathrm{X}$ dan $\mathrm{Y}$ termasuk dalam kategori hubungan yang rendah. Arah hubungan keduanya adalah positif, yang memperlihatkan bahwa semakin tinggi pemahaman remaja tentang ibadah yang sejati akan membuat pertumbuhan kerohanian remaja meningkat. Demikian sebaliknya.

Dari hasil analisis juga diperoleh nilai $\mathrm{r}_{\mathrm{yx}}^{2}$ (koefisien determinasi) sebesar 0,032 atau 3,2\%. Artinya sumbangan variabel Pemahaman Ibadah Yang Sejati Berdasarkan Roma 12:1-2 dalam membentuk variabel Pertumbuhan Kerohanian Remaja GPPS Maranatha Diski adalah 3,2\% sedangkan sisanya sebesar 96,8\% dijelaskan oleh sebab-sebab lain di luar model penelitian. 
Disimpulkan bahwa hubungan Pemahaman Ibadah Yang Sejati Berdasarkan Roma 12:1-2 adalah sangat signifikan dengan Pertumbuhan Kerohanian Remaja GPPS Maranatha Diski pada $\alpha<0.01$. Jika dilihat dari populasi, diperoleh nilai $\mathrm{t}$ sebesar 2.999 dan ternyata sangat signifikan pada $\alpha<0,01$. Berarti, variabel Pemahaman Ibadah Yang Sejati Berdasarkan Roma 12:1-2 secara sangat signifikan berpengaruh terhadap variabel pertumbuhan kerohanian.

\section{PENUTUP}

Berdasarkan hasil pengolahan data dan pembahasan yang telah dilakukan, maka peneliti akan menyimpulkan hasil penelitian bahwa Pengaruh Pemahaman Ibadah Yang Sejati Berdasarkan Roma 12:1-2 cenderung tidak paham. Hasil uji statistik Pemahaman Ibadah Yang Sejati Berdasarkan Roma 12:1-2 dalam kategori cukup paham di dalam tabel klas interval dengan nilai Lower Bound dan Upper Bound yakni 103.82 s/d 105.46 dengan confidence interval pada taraf signifikansi $<0,05$. Adapun rinciannya menurut masing-masing dimensi dari variabel (X) adalah: Dimensi Mempersembahkan Tubuh Sebagai Persembahan Yang Hidup $\left(\mathrm{Dx}_{1}\right)$, berada pada kategori cukup paham menuju paham dalam tabel klas interval dengan nilai Lower Bound dan Upper Bound yakni 26.04 s/d 26.60. Dimensi Mempersembahkan Tubuh Sebagai Persembahan Yang Kudus $\left(\mathrm{Dx}_{2}\right)$ dari variabel berada pada paham di dalam tabel klas interval, dengan nilai Lower Bound dan Upper Bound yakni 41.37 s/d 42.19. Dimensi Mempersembahkan Tubuh Sebagai Persembahan Yang Berkenan (Dx3) dari variable berada pada cukup paham di dalam tabel klas interval, dengan nilai Lower Bound dan Upper Bound 36.18 s/d 36.18. Jadi dari hasil penelitian hipotesis awal, yaitu Pemahaman Ibadah Yang Sejati cenderung tidak paham tidak terbukti. Karena berdasarkan uji coba hipotesa dimensi $\mathrm{X} 1, \mathrm{X} 2$ dan $\mathrm{X} 3$ tingkat pemahaman ibadah yang sejati cenderung cukup paham menuju paham.

Hipotesis kedua dalam penelitian ini yaitu kecenderungan Pertumbuhan Kerohanian Remaja GPPS Maranatha Diski adalah cukup paham. Hasil uji statistik menemukan bahwa Pertumbuhan Kerohanian Remaja GPPS Maranatha Diski dalam kategori cukup paham, dengan nilai Lower Bound dan Upper Bound yakni 73.33 s/d 81.15 Adapun rinciannya menurut masing-masing dimensi dari variabel Pertumbuhan Kerohanian Remaja GPPS Maranatha Diski (Y) adalah 
sebagai berikut: Dimensi Suka Beribadah $\left(\mathrm{Dy}_{1}\right)$ dari variabel Pertumbuhan Kerohanian Remaja GPPS Maranatha Diski berada pada kategori paham di dalam tabel klas interval, dengan nilai Lower Bound dan Upper Bound yakni 39.10 s/d 40.17. Dimensi Memiliki Karakter Kristus $\left(\mathrm{Dy}_{2}\right)$ dari variabel Pertumbuhan Kerohanian Remaja GPPS Maranatha Diski berada pada kategori cukup paham dalam tabel klas interval dengan nilai Lower Bound dan Upper Bound yakni 21.89 s/d 22.42. Dimensi Melayani Tuhan (DY3) dari variable Pertumbuhan Kerohanian Remaja GPPS Maranatha Diski berada pada kategori cukup paham dalam tabel klas interval dengan nilai Lower Bound dan Upper Bound yakni 18.23 s/d 18.16.Jadi berdasarkan hasil penelitian di atas, maka disimpulkan bahwa Pemahaman Ibadah Sejati Berdasarkan Roma 12:1-2 terhadap...

GPPS Maranatha Diski cenderung cukup paham adalah terbukti.

Hipotesis ketiga awal dalam penelitian ini adalah Pengaruh Pemahaman Ibadah Yang Sejati Berdasarkan Roma 12:1-2 Terhadap Pertumbuhan Kerohanian Remaja GPPS Maranatha Diski adalah paham. Adapun rincian hasil uji hipotesisnya adalah sebagai berikut: Terdapat Hubungan Pemahaman Ibadah Yang Sejati Berdasarkan Roma 12:1-2 (X) Terhadap Pertumbuhan Kerohanian Remaja GPPS Maranatha Diski (Y) dengan nilai $\mathrm{r}_{\mathrm{yx}}$ sebesar 0,178 dan bernilai positif. Artinya hubungan antara dua variabel dalam kategori tidak paham. Sumbangan Pemahaman Ibadah Yang Sejati Berdasarkan Roma 12:1-2 (X) terhadap Pertumbuhan Kerohanian Remaja GPPS Maranatha Diski (Y) dengan nilai $\mathrm{r}_{\mathrm{yx}}{ }^{2}$ (koefisien determinasi) sebesar 0.032 atau 3,2\%. Artinya variabel $\mathrm{X}$ mempengaruhi variabel Y sebesar 3,2\% dan sisanya 96,8\% dipengaruhi oleh faktor yang lain di luar model penelitian. Terdapat hubungan Pemahaman Ibadah Yang Sejati Berdasarkan Roma 12:1-2 (X) terhadap Pertumbuhan Kerohanian Remaja GPPS Maranatha Diski (Y) yang signifikan antara variabel dengan nilai $\mathrm{F}$ sebesar 8.991 yang ternyata sangat signifikan pada $\alpha<0.01$. Terdapat pengaruh secara signifikan antara variabel Pemahaman Ibadah Yang Sejati Berdasarkan Roma 12:1-2 (X) terhadap Pertumbuhan Kerohanian Remaja GPPS Maranatha Diski (Y) dengan nilai t sebesar 2,999 dan ternyata sangat signifikan pada $\alpha<$ 0,01. Persamaan garis regresi linier dihasilkan $\hat{Y}=59,591+0,197$ X. Artinya, setiap adanya Pemahaman Ibadah Yang Sejati Berdasarkan Roma 12:1-2 
meningkat satu kali, maka Pertumbuhan Kerohanian Remaja GPPS Maranatha Diski akan meningkat 0,197 kali. Berdasarkan hasil penelitian di atas, maka disimpulkan bahwa hipotesa ketiga dalam penelitian ini yaitu Pemahaman Ibadah Yang Sejati Berdasarkan Roma 12:1-2 terhadap Pertumbuhan Kerohanian Remaja GPPS Maranatha Diski variabel cenderung paham tidak terbukti.

Sedangkan saran adalah kepada Departemen Pemuda dan Remaja GPPS Maranatha Diski agar menghimbau kepada seluruh orang tua agar lebih memiliki waktu bersama dengan anak remaja mereka dan memiliki mezbah keluarga. Seluruh remaja GPPS Maranatha Diski hendaknya merubah pola pikir bahwa ibadah yang sejati tidak hanya rajin ke gereja tetapi lebih dari pada itu harus memberikan tubuh secara utuh baik pikiran, perasaan, perkataan, perbuatan, dan lain sebagainya untuk menyenangkan Tuhan Yesus. Mengevaluasi peranan orang tua, Sekolah Minggu dan remaja tentang pelayanan kepada remaja

\section{DAFTAR RUJUKAN}

Dorothy I. Marx. 2002. Itu 'Kan Boleh? Bandung: Kalam Hidup

Drane, John. 2010. Memahami Perjanjian Baru. Jakarta: Bpk Gunung Mulia

Enns, Paul. 2003. The Moody Handbook of Theology. Malang: SAAT.

Gunarsa, Singgih D. 1986. Psikologi Perkembangan Anak dan Remaja. Jakarta: BPK Gunung Mulia .

Hagelberg, Dave. 2007. Tafisran Roma dari Bahasa Yunani. Bandung: Kalam Hidup

Harrison, Everett F. 2008. The Wycliffe Bible Commentary "Tafsiran ALkitab Wycliffe Volume 3 Perjanjian Baru”. Malang: Gandum Mas

Herlianto. 2000. Ecstasy dan Putauw, Tantangan Bagi Pelayanan Kristiani. Bandung: Kalam Hidup

Jaffray, R.A. 2007. Tafsiran Surat Roma. Bandung: Kalam Hidup

Marbun, R.M.G. 1993. Pokok-pokok Pemahaman Iman GKPI. Pematang Siantar: Kantor Pusat GKPI

Pratt Jr, Richard L. 2014. Menaklukkan Segala Pikiran Kepada Kristus. Malang: Literatur SAAT .

Riemer, G. 1995. Cermin Injil. Jakarta: Yayasan Komunikasi Bina Kasih/OMF 
Rim, Yeremia. 1994. Iman dan Ibadah yang Otentik. Yogyakarta: Andi

Shelly, Judith Allen. 2003. Kebutuhan Rohani Anak Pedoman Untuk Para Orang Tua, Guru dan Perawat. Bandung: Kalam Hidup

Sidajabat, B.S. 2008. Membesarkan Anak Dengan Kreatif "Panduan Menanamkan Iman \& Moral Kepada Anak Sejak Dini”. Yogyakarta: Andi 